\title{
Detailed In Vitro Pharmacological Characterization of the Clinically Viable Nociceptin/Orphanin FQ Peptide Receptor Antagonist BTRX-246040
}

\author{
Federica Ferrari, Sabrina Rizzo, Chiara Ruzza, and Girolamo Calo \\ Department of Medical Sciences, Section of Pharmacology, University of Ferrara, Ferrara, Italy (F.F., S.R., C.R., G.C.) and \\ Technopole of Ferrara, LTTA Laboratory for Advanced Therapies, Ferrara, Italy (C.R.)
}

Received September 24, 2019; accepted January 7, 2020

\begin{abstract}
The peptide nociceptin/orphanin $F Q(N / O F Q)$ is the natural ligand of the N/OFQ receptor (NOP), which is widely expressed in the central and peripheral nervous system. Selective NOP antagonists are worthy of testing as innovative drugs to treat depression, Parkinson disease, and drug abuse. The aim of this study was to perform a detailed in vitro characterization of BTRX-246040 (also known as LY2940094, [2-[4-[(2-chloro-4,4-difluoro-spiro[5H-thieno [2,3-c]pyran-7,4'-piperidine]-1'-yl)methyl]-3-methyl-pyrazol-1yl]-3-pyridyl]methanol), a novel NOP antagonist that has been already studied in humans. BTRX-246040 has been tested in vitro in the following assays: calcium mobilization in cells expressing NOP and classic opioid receptors and chimeric G proteins, bioluminescence resonance energy transfer assay measuring NOP interaction with $\mathrm{G}$ proteins and $\beta$-arrestins, the label-free dynamic mass redistribution assay, and the electrically stimulated
\end{abstract}

mouse vas deferens. BTRX-246040 was systematically compared with the standard NOP antagonist SB-612111. In all assays, BTRX246040 behaves as a pure and selective antagonist at human recombinant and murine native NOP receptors displaying 3-10-fold higher potency than the standard antagonist SB-612111. BTRX246040 is an essential pharmacological tool to further investigate the therapeutic potential of NOP antagonists in preclinical and clinical studies.

\section{SIGNIFICANCE STATEMENT}

NOP antagonists may be innovative antidepressant drugs. In this research, the novel clinically viable NOP antagonist BTRX-246040 has been deeply characterized in vitro in a panel of assays. BTRX-246040 resulted a pure, potent, and selective NOP antagonist.

\section{Introduction}

The peptide nociceptin/orphanin FQ (N/OFQ) is the natural ligand of the N/OFQ receptor (NOP), which is widely expressed in the central and peripheral nervous system (Lambert, 2008). Through the activation of the NOP receptor, N/OFQ regulates different biologic functions and pathologic states (Lambert, 2008). NOP receptor agonists are now under clinical development for the treatment of hypertension (Kantola et al., 2017), urinary incontinence (Angelico et al., 2019), and pain (Calo and Lambert, 2018; Tzschentke et al., 2019). Several chemically diverse NOP antagonists have been described in the literature, including the peptides [Nphe $\left.{ }^{1}\right] \mathrm{N} / \mathrm{OFQ}(1-13)-\mathrm{NH}_{2}$ (Calo et al., 2000) and $\left[\mathrm{NPhe}^{1}{ }^{1} \mathrm{Arg}^{14}{ }^{14} \mathrm{Lys}^{15}\right] \mathrm{N} / \mathrm{OFQ}-\mathrm{NH}^{2}$ (UFP-101) (Calo et al., 2002) and the small molecules J-113397 (Ozaki et al., 2000), SB-612111 (Zaratin et al., 2004), and Compound 24 (C-24) (Goto et al., 2006) [for a review, see Toll et al. (2016) and Zaveri

This work has been financially supported by funds from the University of Ferrara [FAR Grant to G.C.] and the Italian Ministry of Research [Grant PRIN2015WX8Y5B to G.C.].

https://doi.org/10.1124/jpet.119.262865. and Meyer (2019)]. The crystal structure of the NOP receptor in complex with SB-612111 and C-24 24 has been described (Thompson et al., 2012; Miller et al., 2015). The availability of selective antagonists together with mice (Nishi et al., 1997) and rats (Homberg et al., 2009; Rizzi et al., 2011) knockout for the NOP gene allowed researchers to study the consequences of blocking NOP signaling in animal models of pathology. A large series of studies suggest that selective NOP antagonists may represent innovative drugs to treat depression (Gavioli and Calo, 2013) and Parkinson disease (Mercatelli et al., 2019). Moreover, recent findings suggest that treatment of drug abuse might be an additional indication for NOP antagonists (RorickKehn et al., 2016; Kallupi et al., 2017) [see (Ciccocioppo et al., 2019) for a detailed discussion of this topic].

Recently, a novel NOP receptor antagonist, BTRX-246040 (also known as LY2940094, [2-[4-[(2-chloro-4,4-difluoro-spiro[5Hthieno[2,3-c]pyran-7,4'-piperidine]-1'-yl)methyl]-3-methyl-pyrazol1-yl]-3-pyridyl]methanol) has been discovered (Toledo et al., 2014). BTRX-246040 displays high affinity, functional potency, and selectivity for the NOP receptor versus classic opioid proteins (Toledo et al., 2014; Statnick et al., 2016). In rodents,

ABBREVIATIONS: BRET, bioluminescence resonance energy transfer; BTRX-246040, [2-[4-[(2-chloro-4,4-difluoro-spiro[5H-thieno[2,3-c]pyran7,4'-piperidine]-1'-yl)methyl]-3-methyl-pyrazol-1-yl]-3-pyridyl]methanol; CL, confidence limit; C-24, compound 24; DMR, dynamic mass

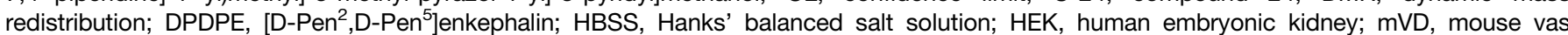
deferens; N/OFQ, nociceptin/orphanin FQ; NOP, N/OFQ peptide receptor; RGFP, recombinant green fluorescent protein; RLuc, Renilla-luciferin 2monooxygenase; UFP-101, [NPhe $\left.{ }^{1}, \mathrm{Arg}^{14}, \mathrm{Lys}^{15}\right] \mathrm{N} / \mathrm{OFQ}-\mathrm{NH}^{2}$. 
BTRX-246040 produced robust antidepressant effects (Post et al., 2016b; Witkin et al., 2016) and displayed potential therapeutic utility in treating alcohol addiction (Rorick-Kehn et al., 2016) and disorders of appetitive behavior (Statnick et al., 2016). Moreover, in small proof-of-concept clinical studies, BTRX-246040 was safe and well tolerated and showed efficacy in depressed (Post et al., 2016b) and alcohol-dependent (Post et al., 2016a) patients. For an updated review on this NOP ligand, see Witkin et al. (2019).

Despite increasing information regarding the in vivo actions of BTRX-246040, our knowledge of the in vitro pharmacological profile of this clinically viable NOP antagonist is very limited. Because a well-grounded knowledge of the pharmacological profile of a receptor ligand is based on the analysis of its actions in different assays and preparations, the aim of this study was to carry out a detailed in vitro pharmacological characterization of BTRX-246040 using multiple assays, including calcium mobilization in cells coexpressing NOP or classic opioid receptors and chimeric G proteins (Camarda et al., 2009; Camarda and Calo, 2013), bioluminescence resonance energy transfer (BRET) assay measuring NOP interaction with $\mathrm{G}$ proteins and $\beta$-arrestins (Malfacini et al., 2015), and the label-free dynamic mass redistribution (DMR) assay (Malfacini et al., 2018). Moreover, to obtain information on the action of BTRX-246040 at native NOP receptors, the last series of experiments were done in the electrically stimulated mouse vas deferens (mVD) (Calò et al., 1996). In all the above mentioned assays, the effects of BTRX-246040 were compared with those of the standard NOP antagonist SB-612111 (Zaratin et al., 2004; Spagnolo et al., 2007).

\section{Material and Methods}

Drugs. N/OFQ, dermorphin, and dynorphin A were synthesized in house. [D-Pen ${ }^{2}, \mathrm{D}-\mathrm{Pen}^{5}$ ] enkephalin (DPDPE) and naltrexone were from Tocris Bioscience (Bristol, UK). SB-612111 and BTRX-246040 were provided by BlackThorn Therapeutics. A total of $1 \mathrm{mM}$ stock solution of N/OFQ, dermorphin, DPDPE, and dynorphin A were made in bidistilled water, whereas BTRX-246040, SB-612111, and naltrexone were solubilized in DMSO $(10 \mathrm{mM})$. Stock solutions were kept at $-20^{\circ} \mathrm{C}$ until use.

Calcium Mobilization Assay. CHO cells expressing the human NOP, kappa, or mu receptor and the C-terminally modified $\mathrm{G} \alpha_{\mathrm{qi} 5}$ as well as CHO cells expressing the delta receptor and the $\mathrm{G} \alpha_{\mathrm{qG66Di5}}$ protein were generated and cultured as previously described (Camarda et al., 2009; Camarda and Calo', 2013). Cells were seeded at a density of 50,000 cells/well into 96-well black, clear-bottom plates 20 hours before the experiment. The day of the experiment, cells were loaded with $2.5 \mathrm{mM}$ probenecid, $3 \mu \mathrm{M}$ of the calciumsensitive fluorescent dye Fluo- 4 AM, and $0.01 \%$ pluronic acid in Hanks' balanced salt solution (HBSS). After 30 minutes, the loading solution was removed, and $100 \mu \mathrm{l} /$ well of HBSS containing $20 \mathrm{mM}$ HEPES, $2.5 \mathrm{mM}$ probenecid, and $500 \mu \mathrm{M}$ Brilliant Black (Sigma Aldrich) were added. Serial dilutions were carried out in HBSS/HEPES (20 mM) buffer (containing $0.02 \%$ bovine serum albumin fraction $\mathrm{V}$ ). The plate reader FlexStation II (Molecular Devices, Sunnyvale, CA) was used to measure fluorescence changes. Online additions were carried out in a volume of $50 \mu \mathrm{l} /$ well. All the experiments were performed at $37^{\circ} \mathrm{C}$. To facilitate drug diffusion into the wells, in antagonism experiments, three cycles of mixing $(25 \mu \mathrm{l}$ from each well moved up and down three times) were performed immediately after antagonist injection. Antagonists were injected 24 minutes before agonists. Agonist effects were expressed as maximum change in percent over the baseline fluorescence. Baseline fluorescence was measured in wells treated with vehicle.
BRET Assay. HEK293 cells coexpressing the different pairs of fusion proteins (NOP-Renilla-luciferin 2-monooxygenase (RLuc)/G $\beta 1$ recombinant green fluorescent protein (RGFP) and NOP-RLuc/ $\beta$ arrestin 2-RGFP) were generated and cultured as previously described (Malfacini et al., 2015). Enriched plasma membrane aliquots, used for G-protein experiments, were prepared from transfected cells as described by Vachon et al. (1987). The protein concentration in membrane preparations was determined with the QPRO-BCA kit (Cyanagen Srl, Bologna, IT) and Beckman DU 520 spectrophotometer (Brea, CA). Membrane experiments were performed in 96-well untreated white opaque microplates, whereas whole-cell experiments were performed in 96-well sterile poly-D-lysine-coated white opaque microplates (PerkinElmer, Waltham, MA). The luminometer Victor 2030 (PerkinElmer) was used. For NOP/G-protein interaction evaluation, cell membranes ( $3 \mu \mathrm{g}$ proteins/well) were suspended in Dulbecco's phosphate-buffered saline. For the determination of NOP/ $\beta$-arrestin 2 interaction, whole cells $(100,000$ cells/well $)$ were seeded 24 hours before the experiment. The day of the experiment, cell medium was removed, and PBS containing $\mathrm{MgCl}_{2}(0.5 \mathrm{mM})$ and $\mathrm{CaCl}_{2}(0.9 \mathrm{mM})$ was added. Coelenterazine $(5 \mu \mathrm{M})$ was injected 15 minutes prior to reading the cell plate. Ligands were added 5 minutes before luminescence reading. In antagonism experiments, BTRX-246040 and SB-612111 were injected into the wells 15 minutes before N/OFQ, and luminescence reading was started 60 minutes after N/OFQ injection. Count per second measured for the RGFP and RLuc light emitted using 510(10) and 460(25) filters (Perkin Elmer), respectively, were used to calculate BRET ratio. All data are expressed as stimulated BRET ratio, i.e., the ratio between count per second from RGFP and RLuc in the presence of ligands minus the BRET ratio in vehicle-treated wells. Maximal agonist effects were expressed as fraction of the N/OFQ maximal effect, which was determined in each plate. All the experiments were performed at room temperature.

DMR Assay. We would like to thank D.G. Lambert (University of Leicester, UK) for kindly providing CHO cells stably expressing the human NOP. Cells were cultured as described by Malfacini et al. (2018). The EnSight Multimode Plate Reader (Perkin Elmer) was used for measuring DMR. Twenty hours before the experiment, cells were seeded (15,000 cells/well/30 $\mu$ l) into fibronectin-coated 384-well DMR microplates. Cells were starved in assay buffer (HBSS with $20 \mathrm{mM}$ HEPES, $0.01 \%$ bovine serum albumin fraction V) for 90 minutes before the test. Serial dilutions of ligands were made in the assay buffer. After reading baseline, compounds were added in a volume of $10 \mu \mathrm{l}$. Antagonists were incubated 30 minutes before N/OFQ injection, and then DMR changes were recorded for 60 minutes. Responses were described as picometer shifts over time (seconds) following subtraction of values from vehicle-treated wells. Maximum picometer modification (Peak) was used to generate concentrationresponse curves. All the experiments were carried out at $37^{\circ} \mathrm{C}$.

Electrically Stimulated mVD Assay. All animal care and experimental procedures conformed to the European Communities Council directives (2010/63/EU) and national regulations (D.L. 26/2014). Studies involving animals are reported in accordance with the Animal Research: Reporting of In Vivo Experiments (ARRIVE) guidelines (Kilkenny et al., 2010). This study was approved by the Italian Ministry of Health (authorization number 302/2017-PR). The experiments were performed on the $\mathrm{mVD}$. The tissues were taken from male, specific-pathogen-free, CD-1 mice (40 g, Laboratory for Preclinical Research of the University of Ferrara, Italy). Mice were housed under standard conditions $\left(22^{\circ} \mathrm{C}\right.$, $55 \%$ humidity, 12-hour light/dark cycle, light on at 7:00 AM) with free access to food and water. Appropriate environmental enrichment was present in each cage. Mice were killed with $\mathrm{CO}_{2}$ overdose. Bioassay experiments were performed as previously described (Calò et al., 1996). The electrically evoked contractions were measured by means of Basile strain gauge isotonic transducers (Basile 7006; Ugo Basile srl, Varese, Italy) and recorder with the Power Laboratory 8 system (AD Instruments, Colorado Springs, CO). After 60 minutes equilibration, the contractions induced by electrical field stimulation were stable. At this time, cumulative concentration-response curves to agonists were performed 
(0.5 log unit steps). Antagonists were added 15 minutes before agonists. Data are expressed as percent of the control twitch. The injection of vehicle did not modify the electrically induced twitch. A total number of 10 mice has been used for this study.

Data Analysis and Terminology. The pharmacological terminology adopted in this paper is consistent with the International Union of Basic and Clinical Pharmacology recommendations (Neubig et al., 2003). All data are expressed as the mean \pm S.E.M. of at least three experiments. For potency values, 95\% confidence limits (CL $\left.\mathrm{C}_{95 \%}\right)$ were indicated. Agonist potencies are given as $\mathrm{pEC}_{50}$, which is the negative logarithm to base 10 of the molar concentration of an agonist that produces $50 \%$ of the maximal effect of that agonist. Concentration-response curves to agonists were fitted to the classic four-parameter logistic nonlinear regression model as follows: Effect $=$ Baseline $+\left(\mathrm{E}_{\max }-\right.$ Baseline $) /\left(1+10^{\left(\operatorname{LogEC}_{50}-\text { Log[compound] }\right) * \text { Hillslope }}\right)$. Curves fitting were performed using PRISM 6.0 (GraphPad Software Inc., San Diego, CA). SB-612111 was assayed at single concentrations against the concentration-response curve to N/OFQ, and its potency was expressed as $\mathrm{pA}_{2}$ derived from the following equation: $\mathrm{pA}_{2}=$ $-\log [(\mathrm{CR}-1) /[\mathrm{A}]]$, assuming a slope value equal to unity, where $\mathrm{CR}$ indicates the ratio between agonist potency in the presence and absence of antagonist, and [A] is the molar concentration of the antagonist (Kenakin, 2004). BTRX-246040 was tested using the classic Schild protocol. Antagonist potencies were expressed either as $\mathrm{pA}_{2}$ or $\mathrm{pK}_{\mathrm{B}}$, depending on the type of antagonism. For competitive type of antagonism, $\mathrm{pA}_{2}$ values were derived from the classic Schild protocol. For noncompetitive types of antagonism, $\mathrm{pK}_{\mathrm{B}}$ values were obtained by the Gaddum method (Gaddum et al., 1955). In practice,
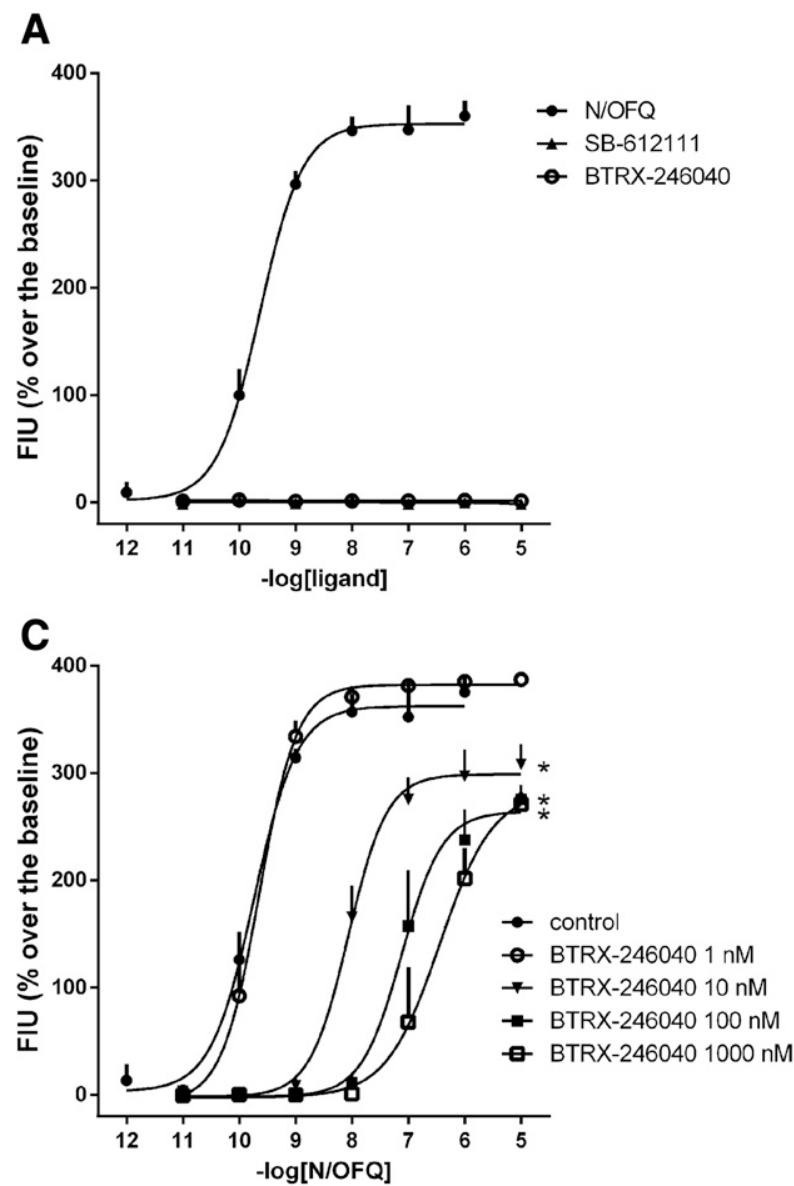

equiactive concentrations of the agonist in the absence ([A]) and presence $\left(\left[\mathrm{A}^{\prime}\right]\right)$ of a noncompetitive antagonist $([\mathrm{B}])$ are compared in a double reciprocal plot describing a straight line, and $\mathrm{pK}_{\mathrm{B}}$ was derived from the following equation: $\mathrm{pK}_{\mathrm{B}}=\log [($ slope -1$) /[\mathrm{B}]]$. Data have been statistically analyzed using one-way ANOVA followed by the Dunnett's post hoc test. $P<0.05$ was considered statistically significant.

\section{Results}

In $\mathrm{CHO}_{\mathrm{NOP}}+$ Gqqi5 cells N/OFQ increased calcium levels in a concentration-dependent manner, showing high potency [pEC ${ }_{50}$ value of 9.65 (9.03-9.98)] and maximal effects $\left(\mathrm{E}_{\max }\right.$ $353 \% \pm 15 \%$ ), whereas SB-612111 and BTRX-246040 were inactive up to $10 \mu \mathrm{M}$ (Fig. 1A). SB-612111, $100 \mathrm{nM}$, shifted to right the concentration-response curve to $\mathrm{N} / \mathrm{OFQ}$ without changing the agonist maximal effect. $\mathrm{A} \mathrm{pA}_{2}$ value of 8.86 (CL ${ }_{95 \%}$ 8.31-9.41) was calculated from these experiments (Fig. 1B). BTRX-246040, in the range of concentrations 1-1000 nM, elicited a concentration-dependent dextral displacement of the concentration-response curve to N/OFQ, with a slight depression of maximal effects at the higher concentrations tested (Fig. 1C). A pA 2 value of 9.27 ( $\mathrm{CL}_{95 \%}$ 8.85-9.69) was extrapolated from the Schild plot (Fig. 1D). In CHO cells expressing chimeric $\mathrm{G}$ proteins and classic opioid receptors, standard agonists (dermorphin for mu, DPDPE for delta, and

\section{B}

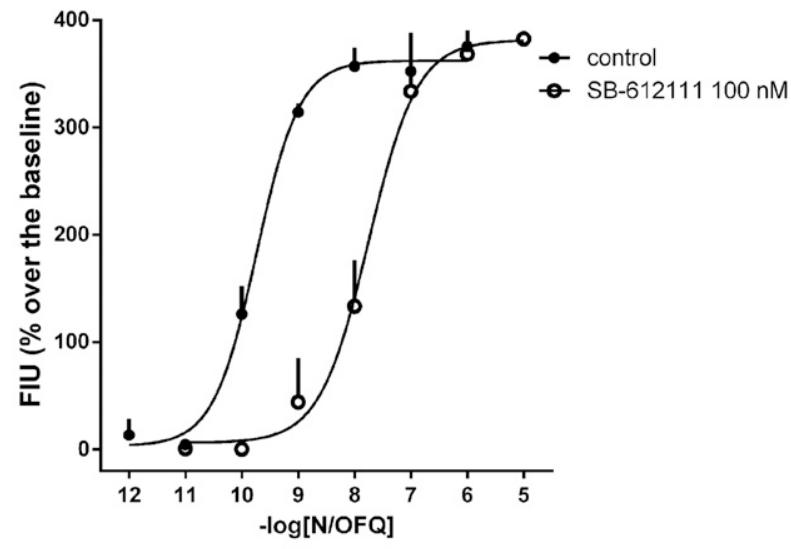

D

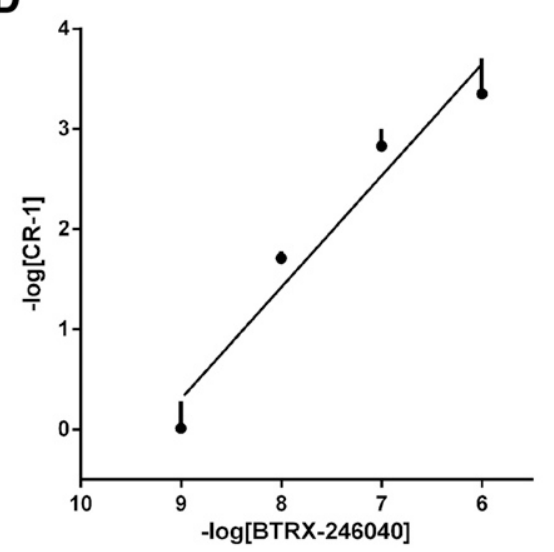

Fig. 1. Calcium mobilization assay. Concentration-response curves to N/OFQ, SB-612111, and BTRX-246040 are displayed in (A). Concentrationresponse curves to N/OFQ in the absence and presence of SB-612111 $100 \mathrm{nM}$ and BTRX-246040 1-1000 nM are shown in (B and C), respectively. The corresponding Schild plot is shown in (D). Data are mean \pm S.E.M. of three (A) or four (B-D) separate experiments performed in duplicate. $* P<0.05$ vs. control, according to one-way ANOVA followed by the Dunnett post hoc test. 
A

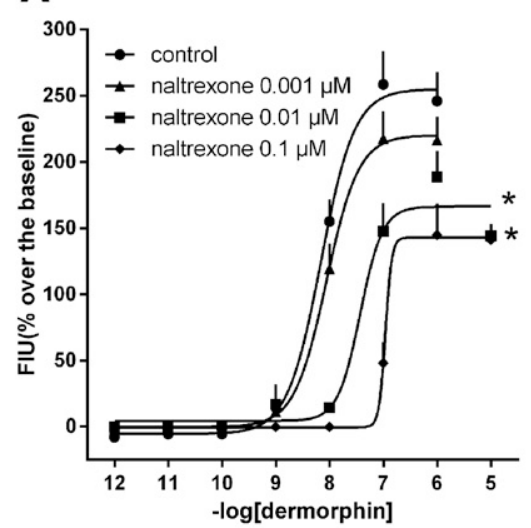

D

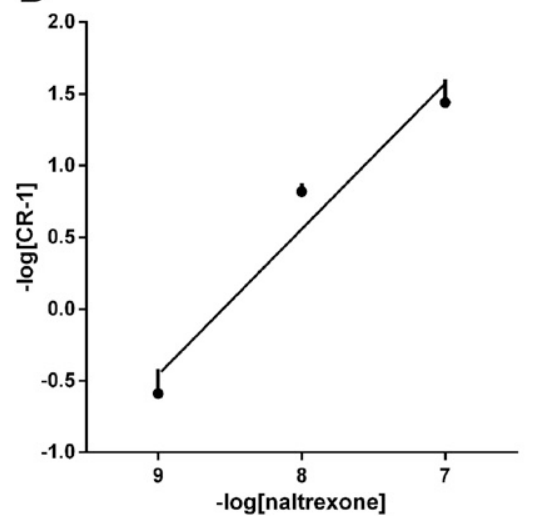

B

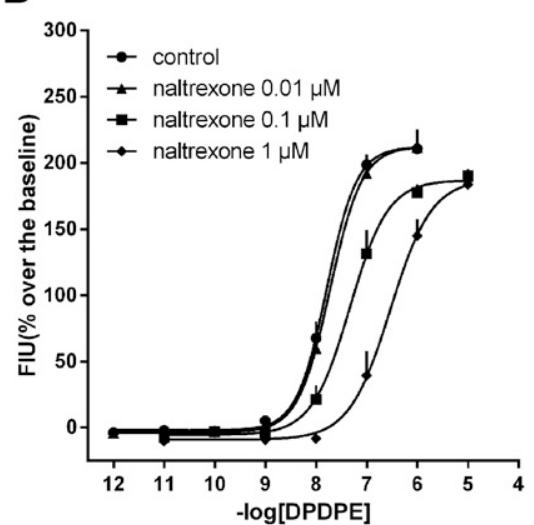

E

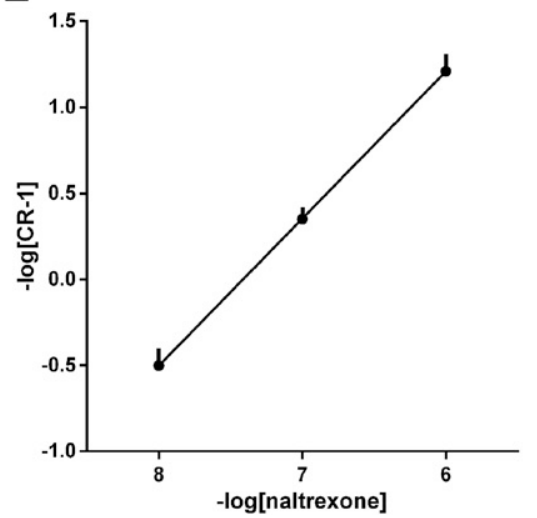

C

kappa

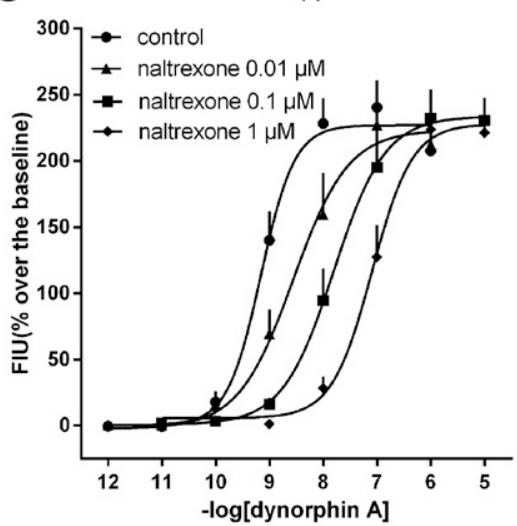

F

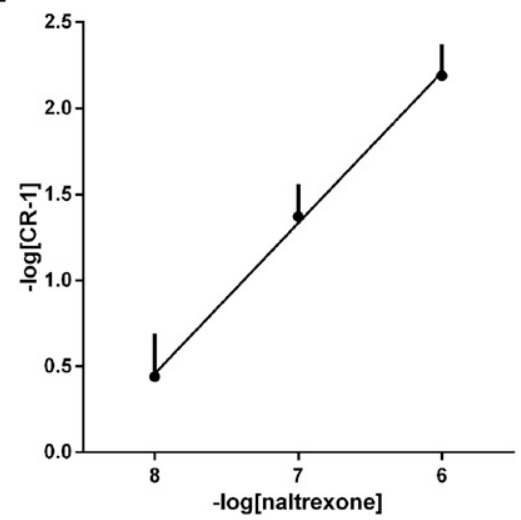

Fig. 2. Calcium mobilization assay in $\mathrm{CHO}$ cells coexpressing the mu (left panels), delta (middle panels), and kappa (right panels) receptors and chimeric G proteins. Concentration-response curves to dermorphin (A), DPDPE (B), and dynorphin A (C) in absence and presence of increasing concentrations $(0.01-1 \mu \mathrm{M})$ of naltrexone. The corresponding Schild plots are shown in (D-F). Data are mean \pm S.E.M. of five separate experiments performed in duplicate. ${ }^{*} P<0.05$ vs. control, according to one-way ANOVA followed by the Dunnett post hoc test.

dynorphin A for kappa receptors) elicited concentrationdependent stimulatory effects that were competitively antagonized by naltrexone with $\mathrm{pA}_{2}$ values of 8.55 ( $\mathrm{CL}_{95 \%}$ 8.07-9.03), 7.42 (CL $95 \%$ 7.17-7.67), and 8.53 (CL $95 \%$ 7.78-9.28), respectively (Fig. 2). At $1 \mu \mathrm{M}$, SB-612111 was inactive at mu and delta receptors but behaved as a low potency antagonist at the kappa receptor ( $\mathrm{pA}_{2}$ 6.14, 5.69-6.59). One micromolar BTRX-246040 was inactive at delta and kappa receptors while producing a small but consistent shift of the concentration-response curve to dermorphin ( $\mathrm{pA}_{2} 6.60,6.34-6.85$ ) (Fig. 3).

In membranes prepared from HEK293 cells stably coexpressing the NOP/RLuc and G $\beta 1 /$ RGFP fusoproteins, N/OFQ promoted receptor/G protein interaction in a concentrationdependent manner, showing high potency [pEC ${ }_{50} 8.94$ (8.73-9.15)] and maximal effects. In parallel experiments, SB-612111 was inactive, whereas BTRX-246040 elicited a very small reduction of the BRET ratio in a concentration-dependent manner (Fig. 4A). SB-612111, $10 \mathrm{nM}$, produced a rightward shift of the concentration-response curve to N/OFQ with no changes of the $\mathrm{E}_{\max } \cdot \mathrm{A} \mathrm{pA}_{2}$ value of $8.96\left(\mathrm{CL}_{95 \%}\right.$ 8.05-9.87) was calculated from these experiments (Fig. 4C). BTRX-246040, in the range of concentrations 1-1000 nM, elicited a concentration-dependent dextral displacement of the concentration-response curve to N/OFQ with a significant reduction of N/OFQ $\mathrm{E}_{\max }$ (Fig. $4 \mathrm{E}$ ). A $\mathrm{pK}_{\mathrm{B}}$ value of 9.53 (8.65-10.41) was calculated for BTRX-246040 from these experiments. In HEK293 cells stably coexpressing the NOP/RLuc and the $\beta$-arrestin 2/RGFP fusoproteins, N/OFQ promoted receptor/ $\beta$-arrestin 2 interaction in a concentrationdependent manner with high potency [pEC $_{50}$ value of 8.23 (8.16-8.30)] and maximal effects, whereas SB-612111 and BTRX-246040 were inactive up to micromolar concentrations (Fig. 4B). SB-612111, $10 \mathrm{nM}$, produced a dextral displacement of the concentration-response curve to N/OFQ without modifying agonist maximal effect, with a $\mathrm{pA}_{2}$ of 8.70 (CL $\mathrm{CL}_{9 \%}$ 7.91-9.49) (Fig. 4D). BTRX-246040, 1-1000 nM, elicited a concentration-dependent rightward shift of the concentrationresponse curve to $\mathrm{N} / \mathrm{OFQ}$, with a large depression of maximal effects (Fig. 4F). A pK $\mathrm{B}_{\mathrm{B}}$ value of 9.16 (8.00-10.32) was calculated from these experiments.

In $\mathrm{CHO}_{\mathrm{NOP}}$ cells, $\mathrm{N} / \mathrm{OFQ}$ elicited a concentration-dependent positive DMR response, whereas SB-612111 was inactive up to micromolar concentrations. BTRX-246040 elicited a very small negative DMR response in a concentration dependent manner (Fig. 5A). In the presence of $100 \mathrm{nM}$ SB-612111, the curve to N/OFQ was rightward shifted with no changes of the agonist maximal effects. $\mathrm{A} \mathrm{pA}_{2}$ value of 8.21 ( $\mathrm{CL}_{95 \%} 7.32-8.75$ ) was derived for SB-612111 from these experiments (Fig. 5B). BTRX-246040, in the 10-1000 nM range, promoted a concentration-dependent dextral displacement of the concentrationresponse curve to $\mathrm{N} / \mathrm{OFQ}$, associated with a small reduction of maximal effects (Fig. 5C). The Schild analysis of these data yielded a $\mathrm{pA}_{2}$ of 8.88 (CL95\% 8.63-9.13) (Fig. 5D).

In the isolated $\mathrm{mVD}, \mathrm{N} / \mathrm{OFQ}$ inhibited the electrically induced twitch in a concentration-dependent manner with 
A

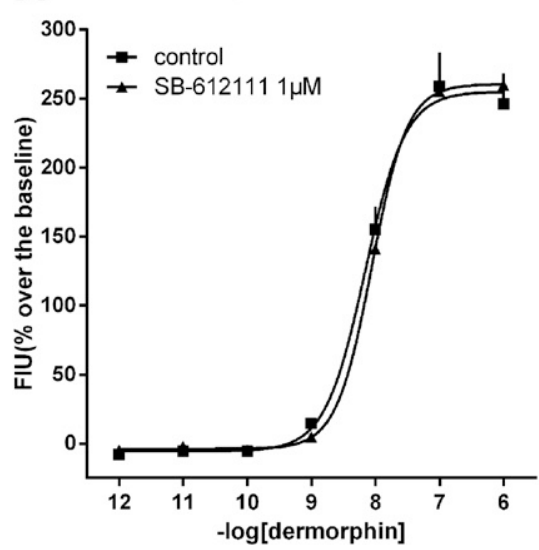

D

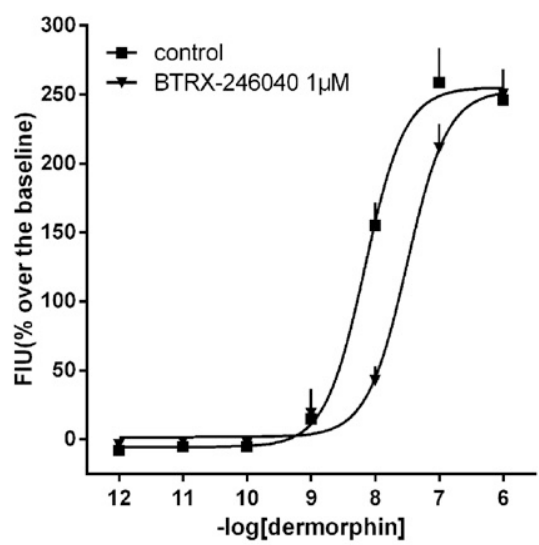

B

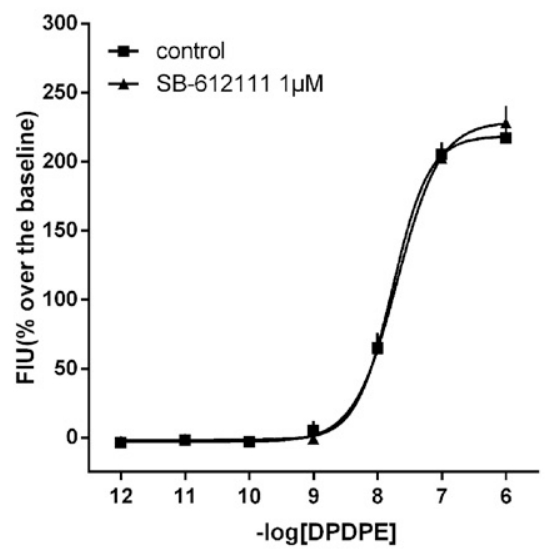

E

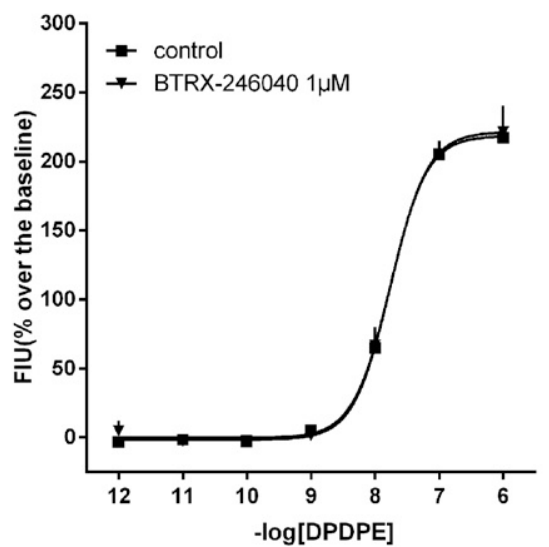

C

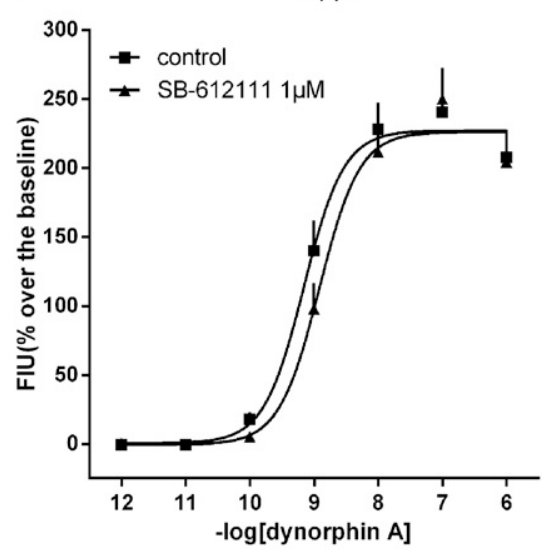

F

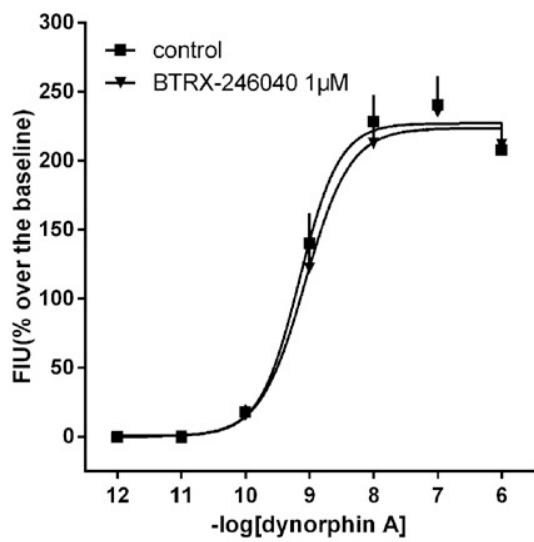

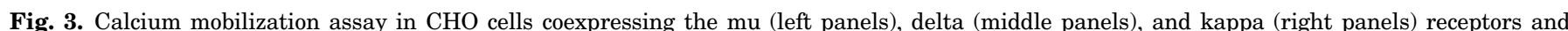

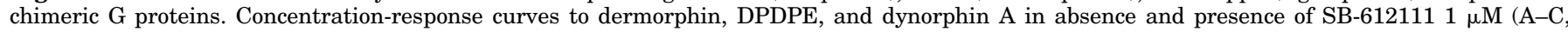
respectively) and BTRX-246040 $1 \mu \mathrm{M}$ (D-F, respectively). Data are mean \pm S.E.M. of five separate experiments performed in duplicate.

a $\mathrm{pEC}_{50}$ of 7.45 (7.28-7.62), whereas SB-612111 and BTRX246040 were inactive up to $1 \mu \mathrm{M}$. At $100 \mathrm{nM}$, SB-612111 elicited a rightward shift of the curve to $\mathrm{N} / \mathrm{OFQ}$, displaying a $\mathrm{pA}_{2}$ value of 7.89 (CL $\mathrm{CL}_{9 \%}$ 7.59-8.19) (Fig. 6A). BTRX-246040, in the 10-1000 $\mathrm{nM}$ range, elicited a concentration-dependent dextral displacement of the concentration-response curve to N/OFQ without changing its $\mathrm{E}_{\max }$ (Fig. 6B). The Schild analysis of this set of data were compatible with a competitive type of interaction and yielded a $\mathrm{pA}_{2}$ value of 8.45 (CL $_{95 \%}$ 7.91-8.99) (Fig. 6C). Finally, under the same experimental conditions, $1 \mu \mathrm{M}$ BTRX-246040 did not modify the inhibitory effects elicited by the delta agonist DPDPE (Fig. 6D).

The results obtained in this study, together with data from literature, have been summarized in Table 1.

\section{Discussion}

The present study extends previous findings (Toledo et al., 2014; Statnick et al., 2016) demonstrating that BTRX-246040 behaves as a pure and selective antagonist at human recombinant and murine native NOP receptors, displaying 3-10-fold higher potency than the standard antagonist SB-612111.

BTRX-246040 behaved as a pure NOP antagonist; this is demonstrated by the lack of effect per se in the calcium mobilization and bioassay studies as well as in previous
GTP $\gamma$ S-binding experiments (Statnick et al., 2016). In NOP/G protein BRET and DMR experiments, BTRX-246040 elicited very small effects opposite to those of N/OFQ, thus suggesting an inverse agonist behavior of this NOP ligand. However, the putative effects of BTRX-246040 were too small to be further investigated. It should be mentioned in this regard that the NOP receptor has very low liability to display constitutive activity. This has been clearly demonstrated in previous receptor/G protein BRET studies in which, under the same experimental conditions, GDP inhibited in a concentrationdependent manner mu and particularly delta opioid receptor interaction with G protein (Vezzi et al., 2013) while producing negligible effects on NOP/G protein interaction (Malfacini et al., 2015). Thus, to investigate the possible inverse agonist activity of BTRX-246040, further studies employing constitutively active mutants of the NOP receptor, e.g., $\mathrm{NOP}_{\mathrm{N} 133 \mathrm{~W}}$ (Kam et al., 2002), or overexpression of NOP receptors via microinjection of cDNA plasmids (Mahmoud et al., 2010) are needed.

As far as type of antagonism is concerned, contrasting results were obtained in the various assays. In fact, although a typical competitive interaction for BTRX-246040 and N/OFQ has been measured in the mVD bioassay, a small but statistically significant depression of N/OFQ maximal effects has been induced by high concentrations of BTRX-246040 in calcium 
A

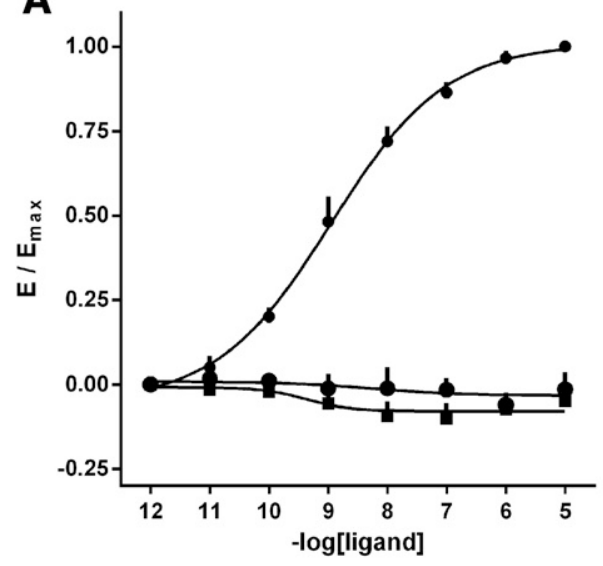

C

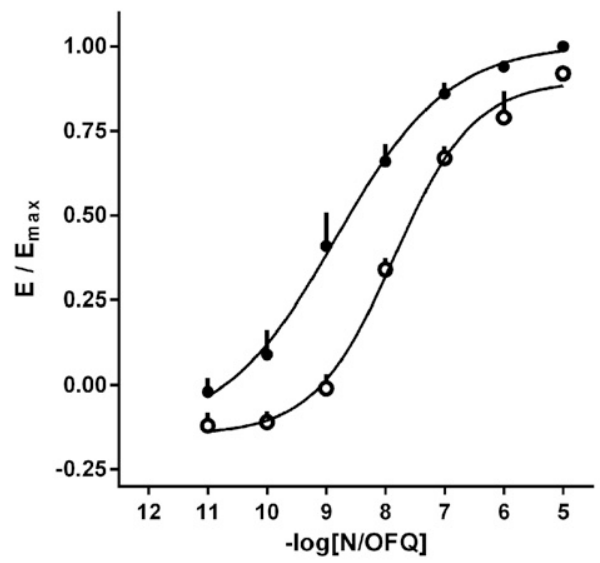

E

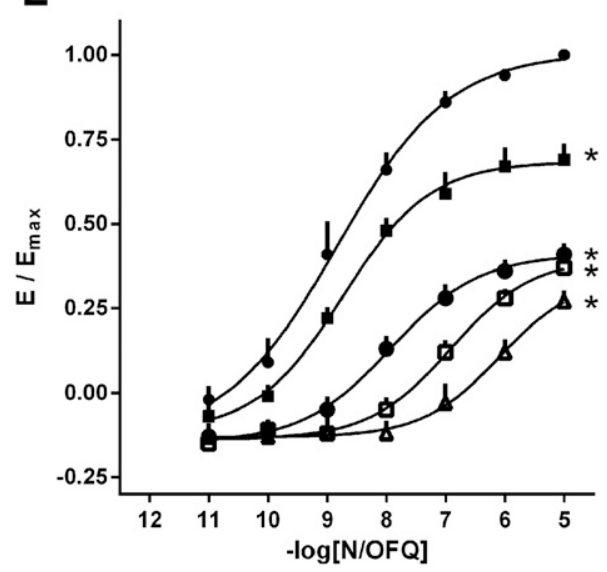

B

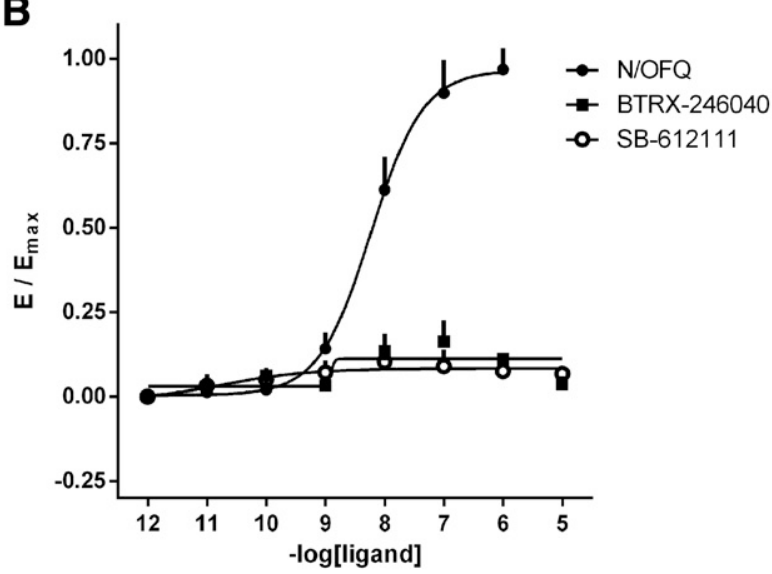

D

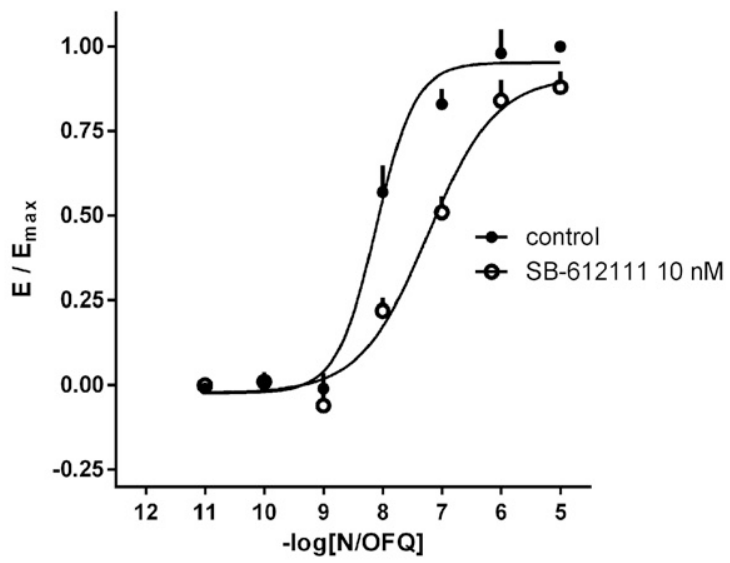

F

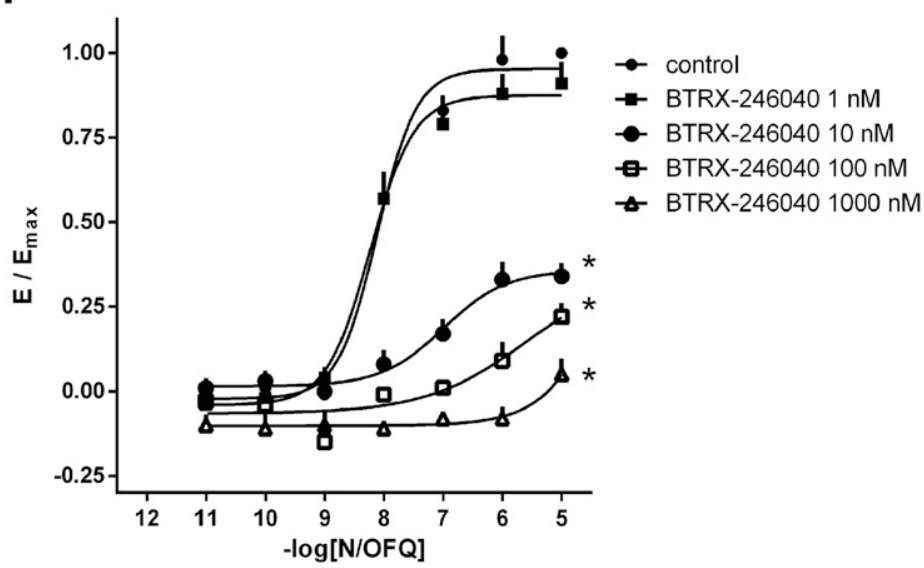

Fig. 4. BRET assay. NOP/G-protein (left panels) and NOP/ $\beta$-arrestin 2 interaction (right panels) experiments. Concentration-response curves to N/OFQ, SB-612111, and BTRX-246040 are displayed in (A and B). Concentration-response curves to N/OFQ in the absence and presence of SB-612111 $10 \mathrm{nM}\left(\mathrm{C}\right.$ and D) and BTRX-246040 1-1000 nM (E and F). Data are mean \pm S.E.M. of five separate experiments performed in duplicate. ${ }^{*} P<0.05$ vs. control, according to one-way ANOVA followed by the Dunnett post hoc test.

mobilization and DMR experiments, whereas a more profound reduction of agonist maximal effects was measured in BRET studies. These variable results deserve attention. For calcium mobilization experiments, it is well known that the rapid and transient nature of calcium peaks causes hemi-equilibrium conditions, and this may lead to an apparent insurmountable behavior of competitive antagonists (Charlton and Vauquelin, 2010). In calcium mobilization studies, the NOP competitive antagonist C-24 generated results very similar to those reported here with BTRX-246040 (Fischetti et al., 2009). In previous NOP/G protein BRET studies, it has been reported that after 5 minutes of incubation with $\mathrm{N} / \mathrm{OFQ}$, the antagonists UFP-101 and J-113397 displayed a surmountable type of antagonism, whereas C-24 and SB-612111 caused a significant depression of N/OFQ maximal effects; this depression was no longer evident by prolonging the incubation time with N/OFQ 
A

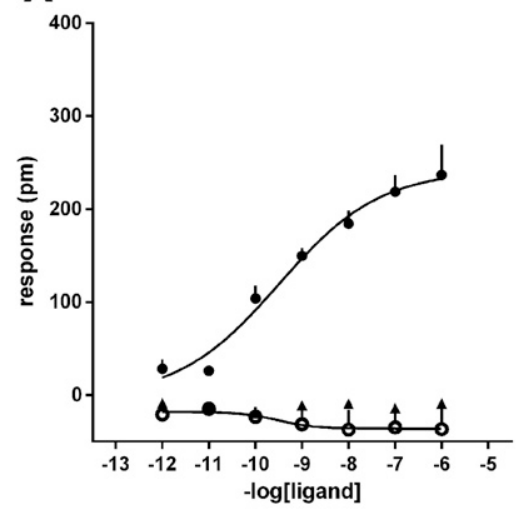

C

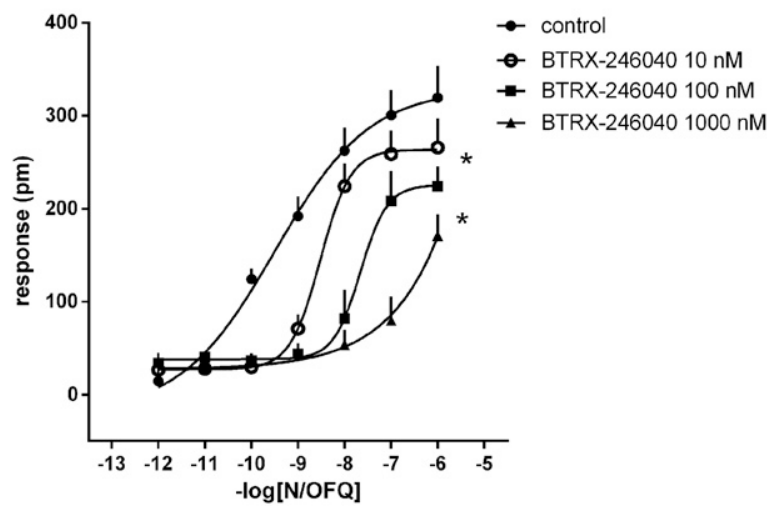

B

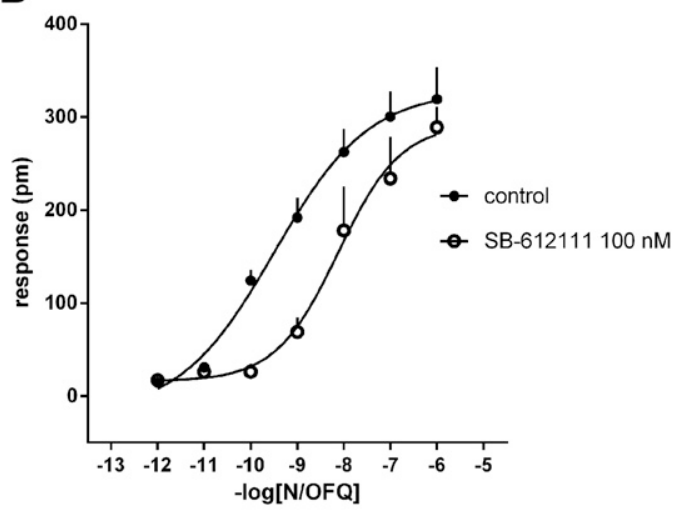

D

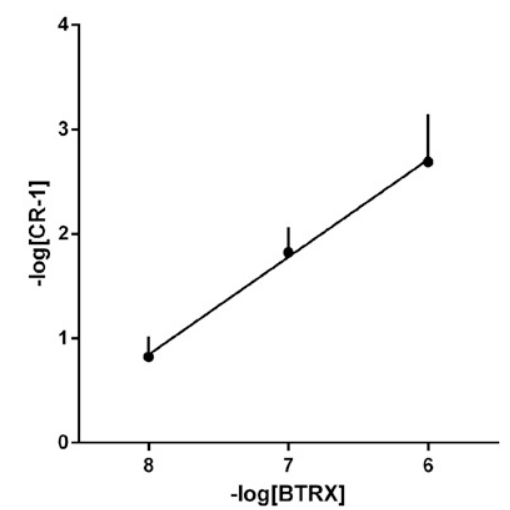

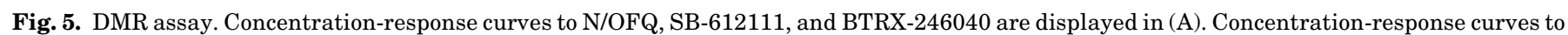

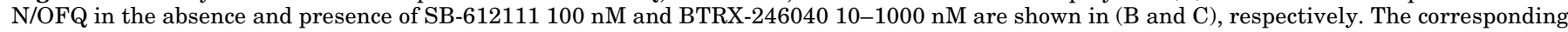

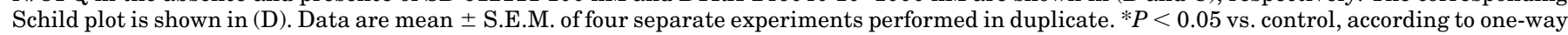
ANOVA followed by the Dunnett post hoc test.

to 15 minutes (Malfacini et al., 2015). Under these experimental conditions (15 minutes incubation time with the agonist), BTRX-246040 displayed an insurmountable type of antagonism (data not shown). Based on the previous findings obtained with SB-612111, we further prolonged incubation time to 30 and 60 minutes. However, even though the depression of $\mathrm{N} / \mathrm{OFQ} \mathrm{E}_{\max }$ was smaller with longer incubation times, a depression of $\mathrm{N} / \mathrm{OFQ}$ maximal effects was still clearly evident after 1 hour of incubation. Because multiflexible docking studies (Della Longa and Arcovito, 2018) clearly demonstrated that BTRX-246040 binds the NOP receptor in the same binding pocket recognizing competitive antagonists such as C-24 (Thompson et al., 2012) and SB-612111 (Miller et al., 2015), it is reasonable to suggest that the BTRX-246040 unsurmountable behavior derives from a very slow rate of offset that does not allow equilibrium to be reached even with prolonged incubation times (Kenakin, 2004). The involvement of kinetic factors in the insurmountable behavior of BTRX-246040 is also suggested by the fact that the maximal effects of N/OFQ were more depressed measuring receptor/ $\beta$-arrestin 2 than receptor/G protein interaction. This may be due to the fact that the kinetics of receptor/G protein interaction is much faster (half time in the range $6-12$ seconds) than that of receptor/ $\beta$-arrestin 2 interaction (half time in the range 60-130 seconds) (Molinari et al., 2010). The above considerations may also explain the insurmountable behavior displayed by BTRX-246040 in DMR experiments; however, they go against the typical competitive interaction displayed by the antagonist in the electrically stimulated $\mathrm{mVD}$ assay. Although a large series of studies demonstrated that the murine NOP receptor displays a pharmacological profile very similar if not identical to that of the human NOP receptor [see table 1 in Malfacini and Calo (2019)], it is still possible that subtle species-specific receptor differences may explain the different behavior of BTRX-246040.

As far as antagonist potency is concerned, BTRX-246040 displayed very high and consistent potency (range 8.45-9.58) in the various assays; these results are in line with the potency (9.77) previously reported in stimulated GTP $\gamma$ S-binding studies as well as with the affinity (9.98) obtained in receptor-binding experiments (Statnick et al., 2016). Importantly, compared with the standard NOP antagonist SB-612111 in parallel experiments, BTRX-246040 was always found to be 3-10-fold more potent. Of note, the values of SB-612111 potency obtained in the present study in the different assays were very close to those previously reported in the literature (Spagnolo et al., 2007; Malfacini et al., 2015, 2018; Ferrari et al., 2017). Therefore, based on present and previous findings [reviewed in Toll et al. (2016), Malfacini and Calo (2019)], we may propose a rank order of potency of antagonists to be BTRX-246040 > SB-612111 > J-113397 > UFP-101 as a NOP pharmacological fingerprint. Moreover, a strong correlation between NOP antagonist potency and receptor thermostability has been previously demonstrated that is consistent with a reduction 
A

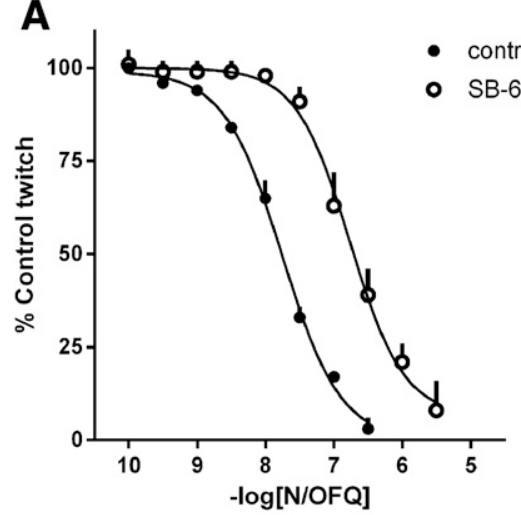

C

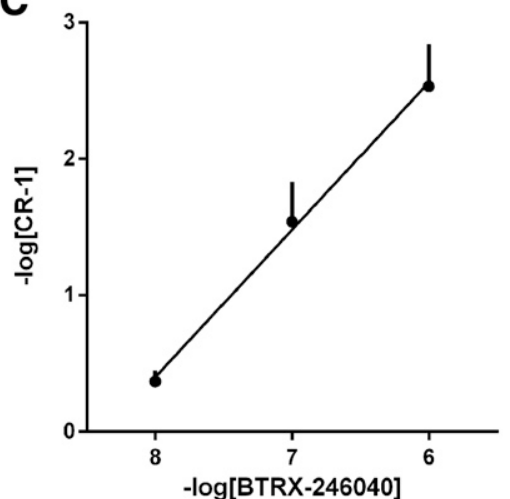

B

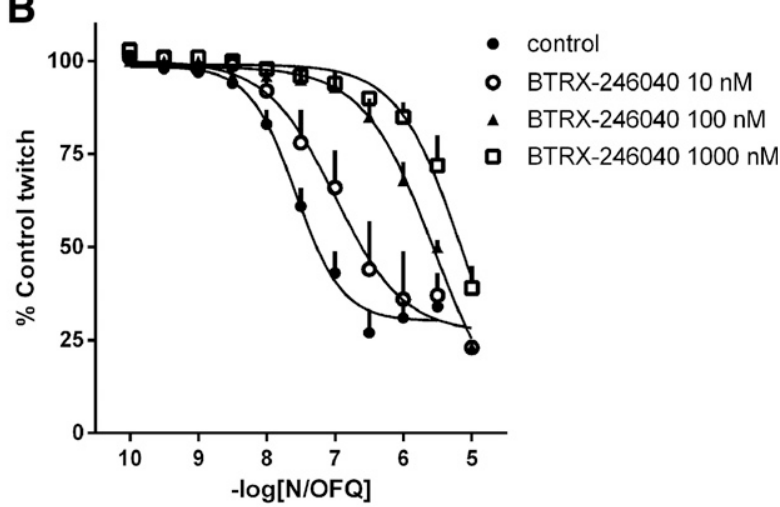

D

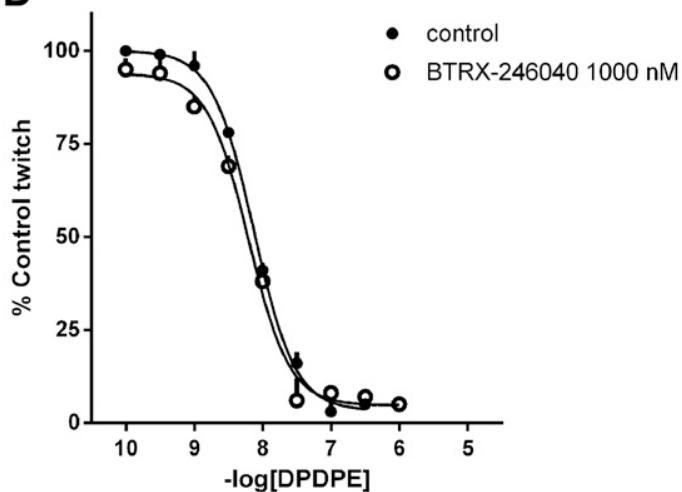

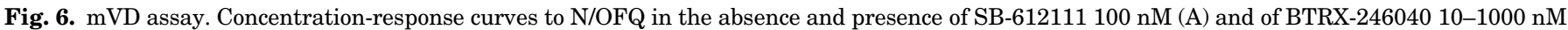

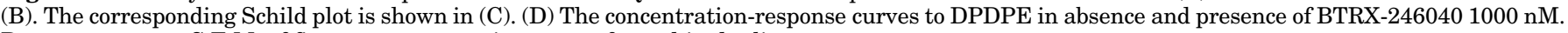
Data are mean \pm S.E.M. of five separate experiments performed in duplicate.

in receptor flexibility by shifting the conformational equilibrium exclusively to the receptor inactive state (Miller et al., 2015). On this basis, it is reasonable to suggest that BTRX-246040 is an ideal candidate for further NOP crystallization studies.

Together with potency, selectivity of action is another key feature of a receptor antagonist. In calcium mobilization studies, BTRX-246040 was approximately 1000-fold selective for NOP over classic opioid receptors, and in bioassay studies, the estimated NOP selectivity of BTRX-246040 over delta receptor was $>300$. These results are perfectly in line with published receptor-binding data (Statnick et al., 2016) that demonstrated that BTRX-246040 affinity is $>3000$-fold higher for NOP than opioid receptors. In parallel experiments,

TABLE 1

Comparison of the NOP affinity and antagonistic potency of BTRX-246040 and SB-612111

Receptor-binding and stimulated GTP $\gamma$ S-binding data are taken from Statnick et al. (2016) for BTRX-246040 and from Spagnolo et al. (2007) for SB-612111. Receptorbinding data are expressed as $\mathrm{pK}_{\mathrm{i}}$, GTP $\gamma \mathrm{S}$-binding and BRET data are expressed as $\mathrm{pK}_{\mathrm{B}}$, and other data are expressed as $\mathrm{pA}_{2}$.

\begin{tabular}{lcc}
\hline & BTRX-246040 & SB-612111 \\
\hline Receptor binding & 9.98 & 9.18 \\
Stimulated GTP $\gamma$ S binding & 9.77 & 9.70 \\
Calcium mobilization & 9.27 & 8.86 \\
BRET G protein & 9.53 & 8.96 \\
BRET/ $\beta$-arrestin 2 & 9.16 & 8.70 \\
DMR & 8.88 & 8.21 \\
Mouse vas deferens & 8.45 & 7.89 \\
\hline
\end{tabular}

SB-612111 displayed high NOP selectivity, confirming previous findings (Zaratin et al., 2004; Spagnolo et al., 2007). Thus, collectively, these findings suggest that BTRX-246040 is more potent and as NOP selective as SB-612111. The high NOP selectivity of BTRX-246040 demonstrated in vitro is corroborated by in vivo findings; in fact, the antidepressant (Witkin et al., 2016) and anorectic (Statnick et al., 2016) actions of BTRX-246040 were no longer evident in mice knockout for the NOP receptor gene.

In conclusion, the results of the present study demonstrated that BTRX-246040 is a pure, potent, and selective antagonist of the NOP receptor. Compared with the standard NOP antagonist SB-612111, BTRX-246040 displays similar high NOP selectivity but is $3-10$-fold more potent. These pharmacodynamic features are associated with great pharmacokinetic properties demonstrated in rodents and humans (Raddad et al., 2016). In addition, the tolerability and safety of BTRX-246040 once-daily dosing of $40 \mathrm{mg}$ up to 8 weeks have been already demonstrated in clinical studies (Witkin et al., 2019). Collectively, these features candidate BTRX-246040 as an essential pharmacological tool to further investigate the therapeutic potential of NOP antagonists as innovative drugs to treat depression (Gavioli and Calo', 2013), Parkinson disease (Mercatelli et al., 2019), and possibly drug abuse (Ciccocioppo et al., 2019) as well as to identify novel conditions/diseases for which the blockade of the NOP receptor is associated with beneficial effects, including traumatic injuries of the central nervous system (Awwad et al., 2018; Sekine et al., 2018), post-traumatic stress disorders (Zhang et al., 2015; 
Genovese and Dobre, 2017), and sepsis (Carvalho et al., 2008; Williams et al., 2008).

\section{Acknowledgments}

We thank BlackThorn Therapeutics (San Francisco, CA) for providing BTRX-246040 and SB-612111.

\section{Authorship Contributions}

Participated in research design: Ferrari, Ruzza, Calo.

Conducted experiments: Ferrari, Rizzo.

Performed data analysis: Ferrari, Rizzo, Ruzza.

Wrote or contributed to the writing of the manuscript: Ruzza, Calo.

\section{References}

Angelico P, Barchielli M, Lazzeri M, Guerrini R, and Caló G (2019) Nociceptin/ orphanin FQ and urinary bladder. Handb Exp Pharmacol 254:347-365.

Awwad HO, Durand CD, Gonzalez LP, Tompkins P, Zhang Y, Lerner MR, Brackett DJ, Sherry DM, Awasthi V, and Standifer KM (2018) Post-blast treatment with Nociceptin/Orphanin FQ peptide (NOP) receptor antagonist reduces brain injuryinduced hypoxia and signaling proteins in vestibulomotor-related brain regions. Behav Brain Res 340:183-194.

Calo' G, Guerrini R, Bigoni R, Rizzi A, Marzola G, Okawa H, Bianchi C, Lambert DG, Salvadori S, and Regoli D (2000) Characterization of [Nphe(1)]nociceptin(1-13) $\mathrm{NH}(2)$, a new selective nociceptin receptor antagonist. $\mathrm{Br} J$ Pharmacol 129 1183-1193.

Calo G and Lambert DG (2018) Nociceptin/orphanin FQ receptor ligands and translational challenges: focus on cebranopadol as an innovative analgesic. $\mathrm{Br}$ $J$ Anaesth 121:1105-1114.

Calò G, Rizzi A, Bogoni G, Neugebauer V, Salvadori S, Guerrini R, Bianchi C, and Regoli D (1996) The mouse vas deferens: a pharmacological preparation sensitive to nociceptin. Eur $J$ Pharmacol 311:R3-R5.

Calo G, Rizzi A, Rizzi D, Bigoni R, Guerrini R, Marzola G, Marti M, McDonald J, Morari M, Lambert DG, et al. (2002) [Nphe1,Arg14,Lys15]nociceptin-NH2, a novel potent and selective antagonist of the nociceptin/orphanin $\mathrm{FQ}$ receptor. Br J Pharmacol 136:303-311.

Camarda V and Calo' G (2013) Chimeric G proteins in fluorimetric calcium assays: experience with opioid receptors. Methods Mol Biol 937:293-306.

Camarda V, Fischetti C, Anzellotti N, Molinari P, Ambrosio C, Kostenis E, Regoli D, Trapella C, Guerrini R, Severo S, et al. (2009) Pharmacological profile of NOP receptors coupled with calcium signaling via the chimeric protein $\mathrm{G}$ alpha qi5. Naunyn Schmiedebergs Arch Pharmacol 379:599-607.

Carvalho D, Petronilho F, Vuolo F, Machado RA, Constantino L, Guerrini R, Calo G, Gavioli EC, Streck EL, and Dal-Pizzol F (2008) The nociceptin/orphanin FQ-NOP receptor antagonist effects on an animal model of sepsis. Intensive Care Med 34: $2284-2290$.

Charlton SJ and Vauquelin G (2010) Elusive equilibrium: the challenge of interpreting receptor pharmacology using calcium assays. $\mathrm{Br} J$ Pharmacol 161: 1250-1265.

Ciccocioppo R, Borruto AM, Domi A, Teshima K, Cannella N, and Weiss F (2019) NOP-related mechanisms in substance use disorders. Handb Exp Pharmacol 254: 187-212.

Della Longa S and Arcovito A (2018) "In silico" study of the binding of two novel antagonists to the nociceptin receptor. J Comput Aided Mol Des 32: $385-400$.

Ferrari F, Malfacini D, Journigan BV, Bird MF, Trapella C, Guerrini R, Lambert DG, Calo' G, and Zaveri NT (2017) In vitro pharmacological characterization of a novel unbiased NOP receptor-selective nonpeptide agonist AT-403. Pharmacol Res Perspect $\mathbf{5}$

Fischetti C, Camarda V, Rizzi A, Pelà M, Trapella C, Guerrini R, McDonald J, Lambert DG, Salvadori S, Regoli D, et al. (2009) Pharmacological characterization of the nociceptin/orphanin FQ receptor non peptide antagonist Compound 24. Eur $J$ Pharmacol 614:50-57.

Gaddum JH, Hameed KA, Hathway DE, and Stephens FF (1955) Quantitative studies of antagonists for 5-hydroxytryptamine. Q J Exp Physiol Cogn Med Sci 40: 49-74.

Gavioli EC and Calo' G (2013) Nociceptin/orphanin FQ receptor antagonists as innovative antidepressant drugs. Pharmacol Ther 140:10-25.

Genovese RF and Dobre S (2017) Mitigation of adverse behavioral impact from predator exposure by the nociceptin/orphanin FQ peptide antagonist J-113397 in rats. Behav Pharmacol 28:521-530.

Goto Y, Arai-Otsuki S, Tachibana Y, Ichikawa D, Ozaki S, Takahashi H, Iwasawa Y, Okamoto O, Okuda S, Ohta H, et al. (2006) Identification of a novel spiropiperidine opioid receptor-like 1 antagonist class by a focused library approach featuring $3 \mathrm{D}$ pharmacophore similarity. J Med Chem 49:847-849.

Homberg JR, Mul JD, de Wit E, and Cuppen E (2009) Complete knockout of the nociceptin/orphanin FQ receptor in the rat does not induce compensatory changes in mu, delta and kappa opioid receptors. Neuroscience 163:308-315.

Kallupi M, Scuppa G, de Guglielmo G, Calo G, Weiss F, Statnick MA, Rorick-Kehn LM, and Ciccocioppo R (2017) Genetic deletion of the nociceptin/orphanin FQ receptor in the rat confers resilience to the development of drug addiction. Neuropsychopharmacology 42:695-706

Kam KW, New DC, and Wong YH (2002) Constitutive activation of the opioid receptor-like (ORL1) receptor by mutation of Asn133 to tryptophan in the third transmembrane region. $J$ Neurochem 83:1461-1470.

Kantola I, Scheinin M, Gulbrandsen T, Meland N, and Smerud KT (2017) Safety, tolerability, and antihypertensive effect of SER100, an opiate receptor-like
1 (ORL-1) partial agonist, in patients with isolated systolic hypertension. Clin Pharmacol Drug Dev 6:584-591.

Kenakin T (2004) A Pharmacology Primer, Elsevier Academic Press, San Diego, CA. Kilkenny C, Browne WJ, Cuthill IC, Emerson M, and Altman DG (2010) Improving bioscience research reporting: the ARRIVE guidelines for reporting animal research. PLoS Biol 8: 1000412.

Lambert DG (2008) The nociceptin/orphanin FQ receptor: a target with broad therapeutic potential. Nat Rev Drug Discov 7:694-710.

Mahmoud S, Margas W, Trapella C, Caló G, and Ruiz-Velasco V (2010) Modulation of silent and constitutively active nociceptin/orphanin FQ receptors by potent receptor antagonists and $\mathrm{Na}+$ ions in rat sympathetic neurons. Mol Pharmacol 77: 804-817.

Malfacini D, Ambrosio C, Gro' MC, Sbraccia M, Trapella C, Guerrini R, Bonora M, Pinton P, Costa T, and Calo' G (2015) Pharmacological profile of nociceptin/ orphanin FQ receptors interacting with G-proteins and $\beta$-arrestins 2. PLoS One 10: $\mathrm{e} 0132865$.

Malfacini D and Caló G (2019) Pharmacological assays for investigating the NOP receptor. Handb Exp Pharmacol 254:69-89.

Malfacini D, Simon K, Trapella C, Guerrini R, Zaveri NT, Kostenis E, and Calo' G (2018) NOP receptor pharmacological profile - a dynamic mass redistribution study. PLoS One 13:e0203021.

Mercatelli D, Pisanò CA, Novello S, and Morari M (2019) NOP receptor ligands and Parkinson's disease. Handb Exp Pharmacol 254:213-232.

Miller RL, Thompson AA, Trapella C, Guerrini R, Malfacini D, Patel N, Han GW, Cherezov V, Caló G, Katritch V, et al. (2015) The importance of ligand-receptor conformational pairs in stabilization: spotlight on the N/OFQ G protein-coupled receptor. Structure 23:2291-2299.

Molinari P, Vezzi V, Sbraccia M, Grò C, Riitano D, Ambrosio C, Casella I, and Costa T (2010) Morphine-like opiates selectively antagonize receptor-arrestin interactions. $J$ Biol Chem 285:12522-12535.

Neubig RR, Spedding M, Kenakin T, and Christopoulos A; International Union of Pharmacology Committee on Receptor Nomenclature and Drug Classification (2003) International Union of Pharmacology Committee on Receptor Nomenclature and Drug Classification. XXXVIII. Update on terms and symbols in quantitative pharmacology. Pharmacol Rev 55:597-606.

Nishi M, Houtani T, Noda Y, Mamiya T, Sato K, Doi T, Kuno J, Takeshima H, Nukada T, Nabeshima T, et al. (1997) Unrestrained nociceptive response and disregulation of hearing ability in mice lacking the nociceptin/orphaninFQ receptor. EMBO J 16:1858-1864.

Ozaki S, Kawamoto H, Itoh Y, Miyaji M, Azuma T, Ichikawa D, Nambu H, Iguchi T, Iwasawa $\mathrm{Y}$, and Ohta $\mathrm{H}$ (2000) In vitro and in vivo pharmacological characterization of J-113397, a potent and selective non-peptidyl ORL1 receptor antagonist. Eur J Pharmacol 402:45-53.

Post A, Smart TS, Jackson K, Mann J, Mohs R, Rorick-Kehn L, Statnick M, Anton R, O'Malley SS, and Wong CJ (2016a) Proof-of-concept study to assess the nociceptin receptor antagonist LY2940094 as a new treatment for alcohol dependence. Alcohol Clin Exp Res 40:1935-1944.

Post A, Smart TS, Krikke-Workel J, Dawson GR, Harmer CJ, Browning M, Jackson K, Kakar R, Mohs R, Statnick M, et al. (2016b) A selective nociceptin receptor antagonist to treat depression: evidence from preclinical and clinical studies [published correction appears in Neuropsychopharmacology (2016) 41:2624]. Neuropsychopharmacology 41:1803-1812.

Raddad E, Chappell A, Meyer J, Wilson A, Ruegg CE, Tauscher J, Statnick MA, Barth V, Zhang X, and Verfaille SJ (2016) Occupancy of nociceptin/orphanin FQ peptide receptors by the antagonist LY2940094 in rats and healthy human subjects. Drug Metab Dispos 44:1536-1542.

Rizzi A, Molinari S, Marti M, Marzola G, and Calo' G (2011) Nociceptin/orphanin FQ receptor knockout rats: in vitro and in vivo studies. Neuropharmacology 60: $572-579$.

Rorick-Kehn LM, Ciccocioppo R, Wong CJ, Witkin JM, Martinez-Grau MA, Stopponi S, Adams BL, Katner JS, Perry KW, Toledo MA, et al. (2016) A novel, orally bioavailable nociceptin receptor antagonist, LY2940094, reduces ethanol selfadministration and ethanol seeking in animal models. Alcohol Clin Exp Res $\mathbf{4 0}$ 945-954.

Sekine Y, Siegel CS, Sekine-Konno T, Cafferty WBJ, and Strittmatter SM (2018) The nociceptin receptor inhibits axonal regeneration and recovery from spinal cord injury. Sci Signal 11

Spagnolo B, Carrà G, Fantin M, Fischetti C, Hebbes C, McDonald J, Barnes TA, Rizzi A, Trapella C, Fanton G, et al. (2007) Pharmacological characterization of the nociceptin/orphanin FQ receptor antagonist SB-612111 [(-)-cis-1methyl-7-[[4-(2,6-dichlorophenyl)piperidin-1-yl]methyl]-6,7,8,9-tetrahydro-5Hbenzocyclohepten-5-ol]: in vitro studies. $J$ Pharmacol Exp Ther 321:961-967.

Statnick MA, Chen Y, Ansonoff M, Witkin JM, Rorick-Kehn L, Suter TM, Song M, Hu C, Lafuente C, Jiménez A, et al. (2016) A novel nociceptin receptor antagonist LY2940094 inhibits excessive feeding behavior in rodents: a possible mechanism for the treatment of binge eating disorder. J Pharmacol Exp Ther 356:493-502.

Thompson AA, Liu W, Chun E, Katritch V, Wu H, Vardy E, Huang XP, Trapella C, Guerrini R, Calo G, et al. (2012) Structure of the nociceptin/orphanin FQ receptor in complex with a peptide mimetic. Nature 485:395-399.

Toledo MA, Pedregal C, Lafuente C, Diaz N, Martinez-Grau MA, Jiménez A, Benito A, Torrado A, Mateos C, Joshi EM, et al. (2014) Discovery of a novel series of orally active nociceptin/orphanin FQ (NOP) receptor antagonists based on a dihydrospiro(piperidine-4,7'-thieno[2,3-c]pyran) scaffold. J Med Chem 57:3418-3429.

Toll L, Bruchas MR, Calo' G, Cox BM, and Zaveri NT (2016) Nociceptin/orphanin FQ receptor structure, signaling, ligands, functions, and interactions with opioid systems. Pharmacol Rev 68:419-457.

Tzschentke TM, Linz K, Koch T, and Christoph T (2019) Cebranopadol: a novel firstin-class potent analgesic acting via NOP and opioid receptors. Handb Exp Pharmacol 254:367-398. 
Vachon L, Costa T, and Herz A (1987) Opioid receptor desensitization in NG 108-15 cells. Differential effects of a full and a partial agonist on the opioid-dependent GTPase. Biochem Pharmacol 36:2889-2897.

Vezzi V, Onaran HO, Molinari P, Guerrini R, Balboni G, Calò G, and Costa T (2013) Ligands raise the constraint that limits constitutive activation in G proteincoupled opioid receptors. J Biol Chem 288:23964-23978.

Williams JP, Thompson JP, Young SP, Gold SJ, McDonald J, Rowbotham DJ, and Lambert DG (2008) Nociceptin and urotensin-II concentrations in critically ill patients with sepsis. Br J Anaesth 100:810-814.

Witkin JM, Rorick-Kehn LM, Benvenga MJ, Adams BL, Gleason SD, Knitowski KM Li X, Chaney S, Falcone JF, Smith JW, et al. (2016) Preclinical findings predicting efficacy and side-effect profile of LY2940094, an antagonist of nociceptin receptors. Pharmacol Res Perspect 4:e0275

Witkin JM, Wallace TL, and Martin WJ (2019) Therapeutic approaches for NOP receptor antagonists in neurobehavioral disorders: clinical studies in major depressive disorder and alcohol use disorder with BTRX-246040 (LY2940094). Handb Exp Pharmacol 254:399-415.
Zaratin PF, Petrone G, Sbacchi M, Garnier M, Fossati C, Petrillo P, Ronzoni S, Giardina GA, and Scheideler MA (2004) Modification of nociception and morphine tolerance by the selective opiate receptor-like orphan receptor antagonist (-)-cis-1-methyl-7-[[4-(2,6-dichlorophenyl)piperidin-1yl]methyl]-6,7,8,9-tetrahydro-5H-benzocyclohepten-5-ol (SB-612111). J Pharmacol Exp Ther 308:454-461.

Zaveri NT and Meyer ME (2019) NOP-targeted nonpeptide ligands. Handb Exp Pharmacol 254:37-67.

Zhang Y, Simpson-Durand CD, and Standifer KM (2015) Nociceptin/orphanin FQ peptide receptor antagonist JTC-801 reverses pain and anxiety symptoms in a rat model of post-traumatic stress disorder. $B r J$ Pharmacol 172:571-582.

Address correspondence to: Dr. Chiara Ruzza, Department of Medical Sciences, Section of Pharmacology, via Fossato di Mortara 19, 44121 Ferrara, Italy. E-mail: chiara.ruzza@unife.it 